\title{
USAGE OF SPECIALIZED LEARNING SUPPORT FOR TEACHING IN TECHNICAL HIGHT SCHOOLS - INTERFEROMETER MEASURING
}

\author{
Jan NOVOTNÝ - Irena HRALOVÁ
}

Abstract: The article describes the partial results of the project team members, which tasks was to create specialized support for the improvement of engineering teaching courses at technical high schools. Supports creating is supported by research carried out by means of tests and surveys.

Key words: Specialized teaching support, technical teaching, research activities

\section{VYUŽITÍ SPECIALIZOVANÝCH UČEBNÍCH OPOR PŘI VÝUCE NA TECHNICKÝCH VYSOKÝCH ŠKOLÁCH - MĚŘENÍ INTERFEROMETREM}

Resumé: Článek popisuje dílčí výsledek členů řešitelského týmu projektu OPVK, který měl za úkol sestavit specializované opory pro zkvalitnění výuky technických předmětů na technických vysokých školách. Tvorba opor je podložena výzkumnými aktivitami formou testů a dotazníkových šetření.

Klíčová slova: Specializovaná opora, technické vzdělávání, výzkumné aktivity.

\section{1 Úvod}

$\mathrm{Na}$ fakultě výrobních technologií a management vznikla díky projektu OPVK zajímavá možnost sestavení specializovaných opor pro laboratorní měření při výuce předmětu Technická fyzika I a Technická fyzika II. Opory jsou zpracovány na základě spolupráce odborníků z oblasti oborových didaktik, pedagogiky a samozřjmě odborníků $\mathrm{z}$ oblasti technické fyziky.

Vznikly tak specializované opory, které umožní studentům efektivnější získávání poznatků při práci v laboratořích. Opory jsou ve zporacované podobě $\mathrm{k}$ dispozici studentům FVTM, kteří je dostanou v elektronické podobě. Po jejich zaběhnutí do praxe je $\mathrm{v}$ plánu, že vyjdou i v tištěné podobě.

V následujícím článku je popsaná jedna měřící úloha, která slouží studentům k lepšímu pochopení dané technické problematiky.

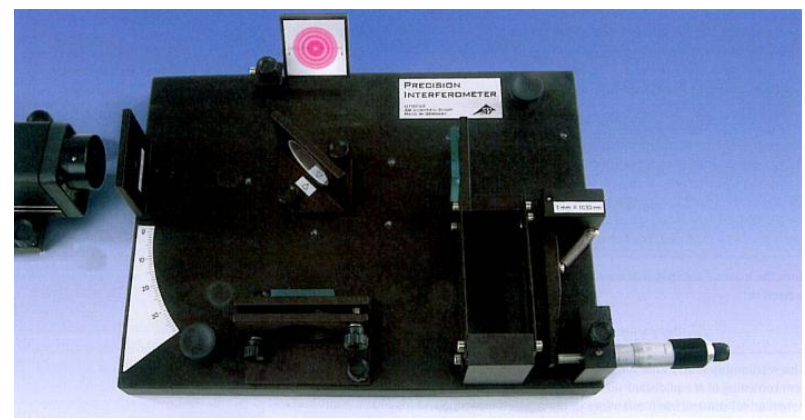

Obr. 1: Michelsonuv interferometr

\section{Interferometr dle Michelsona}

$\mathrm{V}$ Michelsonově interferometru je paprsek koherentního světla vložením rozpůleného zrcátka do jeho cesty rozdělen do dvou paprsků jdoucích v různých směrech. Rozdělené paprsky jsou odráženy zpět podél nich samotných a poté opětovně zkombinované. Na ploše zobrazení se poté ukáže obrazec rušení, který se zřetelně mění, když jsou délky optické dráhy pro každý paprsek změněny rozdělením vlnové délky světla.

\section{Základní principy}

Michelsonův interferometr byl vynalezen A. Michelsonem původně ke znázornění, zda Země může být pozorována $\mathrm{v}$ pohybu pohledem na oblohu, po které se šírí světlo. Jeho navržení se stalo důležitým pro vytváření interferometrických měření, jako např. ve změnách ve vzdálenosti, v tloušt'ce vrstev nebo refraktivních indexech. Divergentní světelný paprsek je rozdělen do dvou paprsků pomocí rozpůleného zrcátka. Tyto paprsky urazí rozdílné dráhy. Ty jsou poté odráženy zpět. Výsledné interferenční obrazce lze poté zobrazit na ploše zobrazení. Výsledný obrazec je vysoce citlivý $\mathrm{k}$ jakýmkoliv rozdílům $\mathrm{v}$ optických drahách zakrytých rozdělenými paprsky. Jestliže refraktivní index zůstává konstantní, stupeň změny geometrických drah může být spočitán, např. změny ve velikosti různých materiálů vzhledem k tepelné roztažnosti. Jestliže naopak je geometrie zachována, mohou být určeny 
refraktivní indexy nebo změny $\mathrm{v}$ nich díky tlaku, teplotě, nebo změnám hustoty.

V závislosti na tom, zda se optické dráhy zvětšují nebo zmenšují v délce, rušící se linky mohou zmizet nebo se objevit uprostřed obrazce. Vztah mezi změnou $\Delta s$ v optických drahách a vlnovou délkou $\lambda$ je následující:

$2 \cdot \Delta s=z \cdot \lambda$

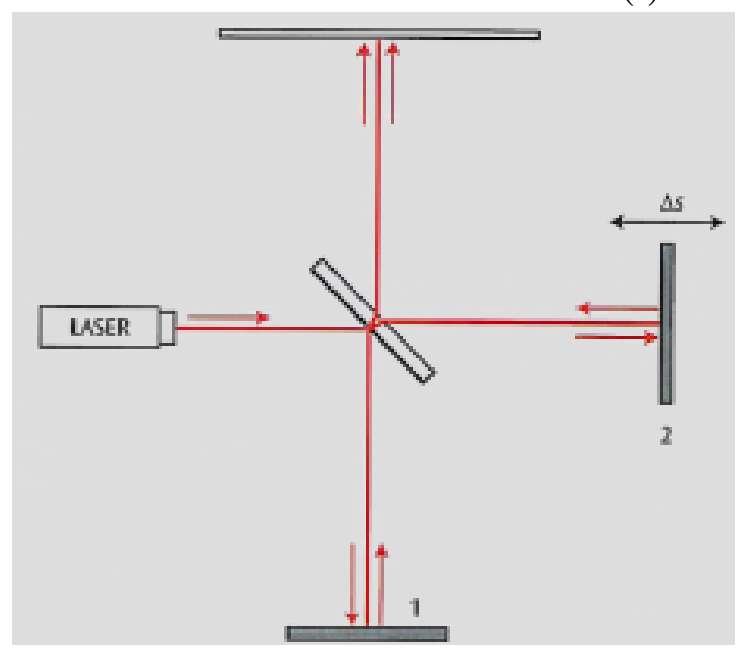

Obr. 2: Princip děleni Optické dráhyv Michelsonově interferometru s pohyblivým zrcátkem.

Číslo $z$ je pozitivní nebo negativní číslo odpovídající číslu rušících se čar mizících nebo zobrazujících se na ploše zobrazení.

Jestliže je měřena vlnová délka světla ve vzduchu pohybem jednoho zrcátka $\mathrm{v}$ presně stanovené vzdálenosti $\Delta x$ prostřednictvím zařízení pro přesné nastavení, refraktivní index může být vypočítaný tak, aby byl $n=1$ pro dobré přiblížení. Změna v optické dráze je:

$\Delta s=\Delta x$

Situace se mění, jestliže vyčerpaná komora o délce $d$ je vložena do pouze jednoho z paprsků. Umožněním průchodu vzduchu do nádoby, zatímco tlak stoupá do hodnoty $p$, se optická dráha mění následovně:

$\Delta s=(n(p)-1) \cdot d=A \cdot p \cdot d$

To je proto, že refraktivní index vzduchu se při konstantní teplotě liší s tlakem způsobem, který může být znázorněn takto:
$n(p)=1+A \cdot p$

\section{Vyhodnocení}

Řešení rovnic (1) a (2) pro vlnovou délku dává rovnici pro vlnovou délku, která záleží na změně pozice zrcadla:

$\lambda=\frac{2 \Delta x}{z}$

\section{Určování refraktivního indexu vzduchu}

Koeficient $A$, který se objevuje v rovnici (4), může být vypočítán za použití následující rovnice:

$$
A=\frac{z^{\lambda}}{2 d p}
$$

\section{Pracovní úkol}

1. Změřte vlnovou délku zelené čáry spektra rtuti Michelsonovým interferometrem. Totéž proved’te pro vlnovou délku $\mathrm{He}$ - Ne laseru.

2. Změřte vzdálenost spektrálních čar sodíkového dubletu Fabryho Perotovým interferometrem.

3. Všechna měření proved'te metodou postupných měření a zpracujte lineární regresí.

4. Stanovte chybu vlnové délky získané v úkolu 1 a 2 lineární regresí. V úkolu 1 diskutujte vliv zadaného převodního koeficientu pro posuv zrcadla u Michelsonova interferometru na systematickou chybu vlnové délky a hledejte jeho vhodnější velikost.

\section{Teoretický úvod}

V Michelsonově interferometru dochází $\mathrm{k}$ interferenci dvou svazků vzniklých rozdělením vstupního svazku polopropustným zrcadlem. Délku dráhy jednoho ze svazků můžeme měnit, čímž měníme fázový rozdíl mezi svazky a interferenční proužky se v důsledku toho pohybují přes zorné pole. Platí pro vlnovou délku použitého světla

$2 l=\lambda k$,

kde $l$ je posun jednoho ze zrcadel v interferometru a $k$ počet proužků prošlých nějakým místem v zorném poli. 
Ve Fabryho - Perotově interferometru dochází $\mathrm{k}$ vícesvazkové interferenci mezi dvěma deskami a měněním vzdálenosti desek dochází stejně jako u Michelsona k posunu proužků. Pokud se použité světlo skládá ze dvou blízkých vlnových délek, vidíme v zorném poli dva systémy proužků, z nichž každý se posouvá různou rychlostí, v důsledku čehož jeden systém „předbíhá“ druhý. Pouhým okem můžeme dostatečně dobře rozlišit př́pady, kdy se systémy překrývají a kdy jsou přesně rozfázované. Opět v [1] je uvedeno, že pro rozdíl dvou vlnových délek platí

$$
\Delta \lambda=\frac{\lambda_{s}^{2}}{2 l},
$$

kde $\lambda_{s}$ je průměr obou vlnových délek a $l$ je vzdálenost mezi dvěma polohami desek, při kterých se systémy proužku překrývají.

\section{Závěr}

Po statistickém vyhodnocení výsledků se potvrdilo, že využití specializovaných opor pro práci a měření $v$ laboratořích fyziky na technických vysokých školách působí na zvýšení úrovně osvojení technického učiva, přispívá ke zvýšení zájmu o technicky zaměřené předměty a pozitivně ovlivňuje vztah $\mathrm{k}$ nim. Na základě vlastního výzkumného šetření, ale i mnoha dalších výzkumů $\mathrm{z}$ podobných oblastí lze usuzovat, že využití specializovaných opor:

- poskytuje vhodné podmínky pro celkový rozvoj studentů cestou samostatného, aktivního a dynamického myšlení, ale i rozhodování a jednání,

- aktivizují při vyhledávání nových informací,

- zvyšují aktivní zájem o věc, a tím i aktivizují pozornost, soustředěnost a logické postupy,

- přispívají ke vzájemné komunikaci a kolektivní práci,
- umožňují kritickou analýzu na základě konfrontace názorů, návrhů, řešení, stanovení pracovních hypotéz,

- zabezpečují organizovanou myšlenkovou činnost a aplikaci osvojených poznatků.

Proto je zřejmé, že i na vysokých školách je třeba věnovat pozornost při př́pravě a tvorbě opor pro studenty a to jak $\mathrm{z}$ hlediska samotného obsahu, tak z hlediska oborových didaktik apod.

I využití specializovaných opor však má i svá úskalí, nebot' vyžadují mnohem více času na prípravu, jisté zkušenosti, nebo i technickou a informační vybavenost školy.

\section{Literatura}

[1] ADAMS, S., ALLDAY, J.: Advanced Physics, Oxford, 2000

[2] BROŽ, J.: Základy fyzikálních měření, Praha, SPN 1967

[2] NOVOTNÝ, J.; HONZÍKOVÁ, J., MACH, P. Alternativni prístupy $k$ technické výchově. 1. vyd., Plzeň : ZČU, 2008. 264 s., př́lohové CD ISBN 978-80-7043-626-4.

[3] ZUKERSTEIN, J. Pracoviště pro výrobu plošných spojů jako prostředek $\mathrm{k}$ uplatňování projektů ve výuce. In Modernizace vysokoškolské výuky technických predmětů. Hradec Králové: VŠP, 1998, s. 318 - 320. ISBN 80-7041-662-9.

\section{Kontaktní adresa:}

Mgr. Irena Hralová,

PhDr. Jan Novotný, Ph.D.

Fakulta výrobních technologií a managementu Univerzita J. E. Purkyně

Na Okraji 1001

40096 Ústí nad Labem, ČR, e-mail: hralova@fvtm.ujep.cz

novotny@fvtm.ujep.cz

Tel.: +420 475285511 